\title{
A summer of disruption
}

\author{
Two environmental disasters in April 2010 have ranked high on the public agenda. The coming months \\ will clarify the extent of the damage, and demand Earth scientists' expertise.
}

North Atlantic winds have received unusual attention this spring. Airline passengers stranded around the world watched closely as the cloud of volcanic ash ejected from Eyjafjallajökull in Iceland was blown across Europe, bringing air travel to a standstill just after Easter. Less than a week later, residents of the southeastern US - along with environmentalists, politicians and the oil industry — hoped for favourable winds to drive away oil pouring from the deep-sea leak off Louisiana.

In both instances, the extent of the crisis is still uncertain at the time of writing. Eyjafjallajökull has not yet come to rest. Further disruption of air travel is expected throughout the summer. Oil from the deepsea borehole is still leaking into the Gulf of Mexico. The magnitude and longevity of the environmental and economic impacts of the leak is anyone's guess at this point in time. It is clear that dealing with the fallout from both events will be expensive. Less clear is who will pay.

The Icelandic eruption is a natural disaster. The question of culpability is therefore not meaningful. However, most of the damage resulted not from the ash itself, but from preventive measures and international regulations that halted aviation. Some airline managers have argued that they cannot be held responsible for the length of time it took the authorities to respond to the eruption, and that they should not be liable for the compensation of stranded passengers' expenses.
Regulations restricting air traffic in ash clouds were initiated after the Mount St Helens eruption in May 1980, almost exactly 30 years ago. At the time, several planes reported temporary engine failure and permanent engine damage after flying through ash. In line with these regulations, the entire European airspace was closed for five days in April 2010, causing huge disruption. However, regulations were relaxed about three weeks later. Air-space closure is now limited to a smaller region around the main ash cloud, but air travel will probably be affected for as long as the volcano produces ash.

The case of the oil leak is quite different, with three companies involved in the accident: BP America is the owner of the well; Transocean owned and operated the now-broken oil rig - Deep Horizon whose sinking initiated the disaster; and Halliburton is the oilfield services company that was responsible for cementing the borehole at the ocean floor that later blew up. These companies are pointing at each other to assign the blame.

BP has accepted full responsibility for the costs. However, without a clearer idea of the consequences of the spill, it remains to be seen how comprehensive this commitment will be. Following the hazard of the oil tanker Exxon Valdez in Prince William Sound, Alaska, in March 1989, the environmental damage persisted for much longer than initially expected. More than 20 years later, oil can still be found on the beaches of
Alaska (Nature Geosci. 3, 96-99, 2010) and the legal battle over the financial responsibilities of the Exxon Shipping Company has been going as long.

The upset and environmental toll associated with both events are intricately linked to the transport sector. Worldwide mobility is one of the pillars of globalization, and it requires smooth airline operations as much as an uninterrupted supply of oil for fuel. But the complete closure of European air travel during a period of glorious spring weather in mid-April has brought home the price we pay every day for the freedom to take a plane anywhere, any time. Those living near busy European aviation routes will have noticed a marked difference in the blueness of the sky and the calm in the air. And without global demand for fuel, the risks of deep-ocean drilling may well have been considered too large to allow the exploitation of oil reserves a long way offshore.

A non-negligible proportion of the cost of this spring's eruptions of ash and oil is likely to fall back on all of us, through increases in taxes, the price of oil or flight tickets, or through the loss of pristine environments. It is in everyone's interest to limit the loss.

It is too late to prevent damage: we cannot geoengineer the winds to blow oil and ash out of the way. But Earth scientists from a wide range of disciplines spanning ecology, volcanology, oceanography, meteorology and seismology can help inform politicians, relief workers and the public on how to minimize the cost, both in ecological and monetary terms.
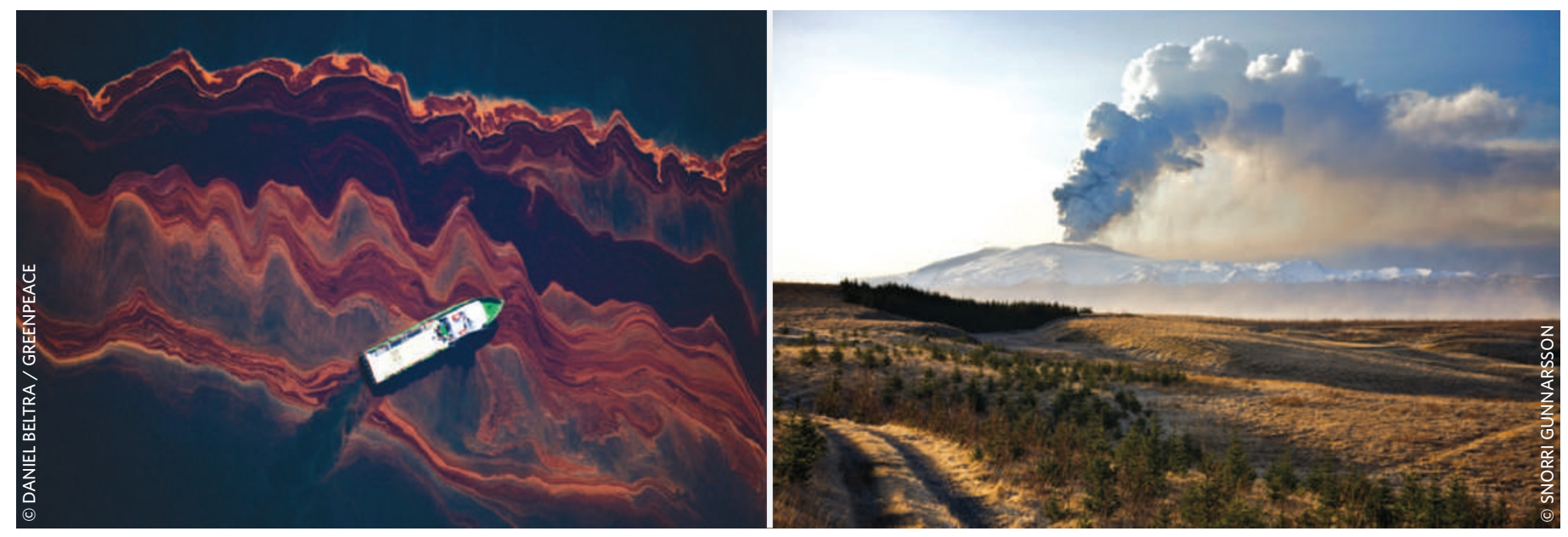